\title{
BACTERIAL DIVERSITY IN LOGGED OVER FOREST OF MINERAL SOIL BEFORE DEVELOPMENT OF OIL PALM PLANTATION IN BELAGA, SARAWAK
}

\section{SHAMSILAWANI AHAMED BAKERI* and MOHD SHAWAL THAKIB MAIDIN*}

\begin{abstract}
Tropical forests are major reservoirs of biodiversity. Soil microbes play important roles in soil fertility. Microbes are sensitive to changes in agricultural activities occurring in the soil, thus they can be used as an indicator for soil quality. This study was conducted to analyse soil microbial biodiversity at logged over forest on mineral soil before development to oil palm plantation, by using denaturing gradient gel electrophoresis combined with $16 S$ rDNA polymerase chain reaction (PCR-DGGE). The average number of bands from PCR-DGGE profiles indicated strip 2 was significantly less diversified than the rest of the sites at $\alpha=0.05$. Shannon-Weaver biodiversity index and Berger-Parker Dominance Index, showed highest diversity in area cultivable for oil palm, followed by the biodiversity strip areas. Bacterial communities were dominated by unclassified bacteria, Acidobacteria, Actinobacteria and $\alpha$-Proteobacteria groups in all types of forest soils. Acidobacteria group was absent in strip 3 where the soil $p H$ was least acidic. Common species found for all sites were, uncultured Acidobacteria bacterium (Acidobacteria), uncultured Actinobacterium clones (Actinobacteria) and uncultured Rhodoplanes sp. ( $\alpha$-Proteobacteria).
\end{abstract}

Keywords: microbial biodiversity, 16S rDNA, logged over forest, oil palm plantation.

Date received: 8 August 2018; Sent for revision: 9 August 2018; Accepted: 13 January 2019; Available online: 12 August 2020.

\section{INTRODUCTION}

Oil palm is one of the world's most rapidly expanding tropical crop, with increased expansion of oil palm planted area in Malaysia from 5.74 million hectares in 2016 to 5.81 million hectares in 2017 (Kushairi et al., 2018). Easy establishment, low maintenance costs, and high productivity makes oil palm a highly profitable tropical oil crop in the world (Wahid et al., 2005). Oil palm growth is suitable for the humid tropical lowlands, nevertheless, in the past several years, tropical forests undergo rapid land clearance for oil palm expansion, with several million hectares of forest converted to oil palm plantation (Koh et al., 2011).

Malaysian Palm Oil Board,

6 Persiaran Institusi, Bandar Baru Bangi,

43000 Kajang, Selangor, Malaysia.

E-mail: shila@mpob.gov.my
Tropical forests as a major reservoir for biodiversity acts in regulating the global climate and nutrient cycling. A large part of the biological diversity of the tropical rainforest ecosystems are made up of bacteria, which are a major component of nutrient cycling and productivity (Van Der Heijden et al., 2008). Logged over forests conversions for agricultural plantations reduces microbial biomass and changes the microbial composition of the soil (Rodrigues et al., 2012). Microbes in the soil are known to be sensitive to changes during these agricultural activities.

Microbial biodiversity is a term related to the bacterial species richness, alongside with the richness of activity each bacterial species goes through during its existence (Erwin, 1991). Molecular techniques to detect and identify bacteria can be done by noncultivation approach, which aims to detect certain microbiota such as unculturable microorganisms 
(Zarkasi and Nazari, 2018). Molecular tools like polymerase chain reaction-denaturing gradient gel electrophoresis (PCR-DGGE) analysis, 16S ribosomal DNA (rDNA), phylogeny tree, fatty acids analysis and protein sequencing have increased the knowledge of microbial life that exist in an ecosystem (Saman et al., 2010). These tools support in the identification and classification of bacteria communities through deoxyribonucleic acid (DNA) extraction of soil samples and nucleotide sequencing of the extracted DNA (Saman et al., 2010). This study was carried out to assess the soil microbial biodiversity at logged over forest areas on mineral soil at Belaga, Sarawak, Malaysia by analysing $16 S$ rDNA PCR-DGGE.

\section{MATERIALS AND METHODS}

\section{Soil Sampling}

Sampling of soil for microbial biodiversity study at Sungai Asap, Belaga, Sarawak was conducted in October 2008 from oil palm cultivable area (OPCA) (representing logged over forest), elevated jungle area; biodiversity strip 1 (S1), disturbed jungle; strip 2 (S2) and riparian jungle area; strip 3 (S3) (Table 1). Ten sampling points were sampled from four randomly selected replicates from each points, which were then, pooled together as one sampling point, with each site at depth of 0-15 cm (Figure 1).

DNA extraction. Microbial deoxyribonucleic acid (DNA) from soil, was directly extracted using Gene Matrix Soil DNA Purification kit (EURx Ltd, Poland). DNA was quantified using Nanophotometer (Implen GMBH, Germany) with absorbance ratio of A260/A280 for nucleic acid measurement.

PCR amplification of $16 s$ rDNA. Primers used were of $16 \mathrm{~S}$ rDNA universal primers, forward (f) with a guanine and cytosine (GC) base clamps, 341f (5'-cgc-ccg-ccg-cgc-gcg-gcg-ggc-ggg-gcg-ggg-gcacgg-ggg-gcc-tac-gg-agg-cag-cag- $\left.3^{\prime}\right)$ and reverse $(\mathrm{r})$, 907r (5'-ccc-cgt-caa-ttc-att-tga-gtt-t-3') (Muyzer et al., 1993) which amplifies the V3-V5 hypervariable region. PCR reaction started at, $94^{\circ} \mathrm{C}$ denaturation for $2 \mathrm{~min}$, followed by annealing with 35 cycles of steps, $94^{\circ} \mathrm{C}$ for $30 \mathrm{~s}, 52.1^{\circ} \mathrm{C}$ for $30 \mathrm{~s}, 72^{\circ} \mathrm{C}$ for $30 \mathrm{~s}$, and final extension at $72^{\circ} \mathrm{C}$ for $2 \mathrm{~min}$. Subsequently, samples were kept at $4^{\circ} \mathrm{C}$ before gel loading.

DGGE. Denaturing gradient of 40\%-80\% (100\% denaturant corresponding to $7 \mathrm{M}$ urea and $40 \%$ ( $\mathrm{vol} /$ vol) deionised formamide on $1.0 \mathrm{mM}$ of $6 \%(\mathrm{w} / \mathrm{v})$ polyacrylamide (37.5:1; acrylamide:bisacrylamide) was used to separate the PCR products. PCR products were run on DGGE at $60^{\circ} \mathrm{C}$ and $60 \mathrm{~V}$ with $1 \mathrm{X}$ TAE buffer for $16 \mathrm{hr}$ and were stained with SYBR ${ }^{\circledR}$ Green I nucleic acid gel stain *10 000X concentrate (Life Technologies, USA) for $60 \mathrm{~min}$. Excised gel was soaked, crushed and stored in $50 \mathrm{ul} \mathrm{TE}$ buffer (1XTE) at $4^{\circ} \mathrm{C}$ for two days to elute the DNA.

\section{PCR Amplification of Purified Band from DGGE}

The eluted microbial DNA was used as a DNA template PCR. Five microlitres of DNA supernatant were used as a template for reamplification of DNA using $16 \mathrm{~S}$ rDNA universal primers, 341f (without GC-clamp) (5'-cct-acg-gga-ggc-agc-ag- $\left.3^{\prime}\right)$ and reverse (r). Positive PCR products were excised from agarose gel after electrophoresed and then purified using QIAquick gel extraction kits.

Recovery and purification of DNA. The excised positive bands in the gel were purified using the protocol in QIA quick gel extraction kit (QIAGEN, Inc., Valencia, CA). The DNA was eluted in a $1.5 \mathrm{ml}$ microcentrifuge tube, submerged with $50 \mu \mathrm{l}$ of EB buffer (10 mMTris. $\mathrm{Cl}, \mathrm{pH} 8.5)$ and kept in $-20^{\circ} \mathrm{C}$.

Nucleotide sequencing. The PCR products were outsourced to First Base Laboratories Sdn Bhd for sequencing analysis. NCBI GenBank database from the website http://www.ncbi.nlm.nih.gov/ was used to do the sequence analysis searches using basic logic alignment search tool (BLAST) service to identify the nearest sequence similarity for the partially sequenced $16 \mathrm{~S}$ rDNA genes.

TABLE 1. LOCATIONS AND PHYSICO-CHEMICAL PROPERTIES OF SITES STUDIED IN BELAGA, SARAWAK, MALAYSIA

\begin{tabular}{lcccc}
\hline Sites & $\begin{array}{c}\text { Oil palm cultivable } \\
\text { area (OPCA) } \\
\text { (logged over forest) }\end{array}$ & $\begin{array}{c}\text { Biodiversity } \\
\text { strip 1 }\end{array}$ & $\begin{array}{c}\text { Biodiversity } \\
\text { strip 2 }\end{array}$ & $\begin{array}{c}\text { Biodiversity } \\
\text { strip 3 }\end{array}$ \\
\hline Forest type & Lowlands & $\begin{array}{c}\text { Secondary jungle, } \\
\text { hilly area }\end{array}$ & $\begin{array}{c}\text { Disturbed } \\
\text { secondary jungle }\end{array}$ & Riparian area \\
Rainfall & \multicolumn{4}{c}{$420 \mathrm{~mm}^{3}$} \\
Moisture content & $16.4 \%$ & $20.0 \%$ & $4.3 \%$ & $24.6 \%$ \\
$\mathrm{pH}$ & 4.7 & 4.5 & 4.7 & 5.1 \\
\hline
\end{tabular}




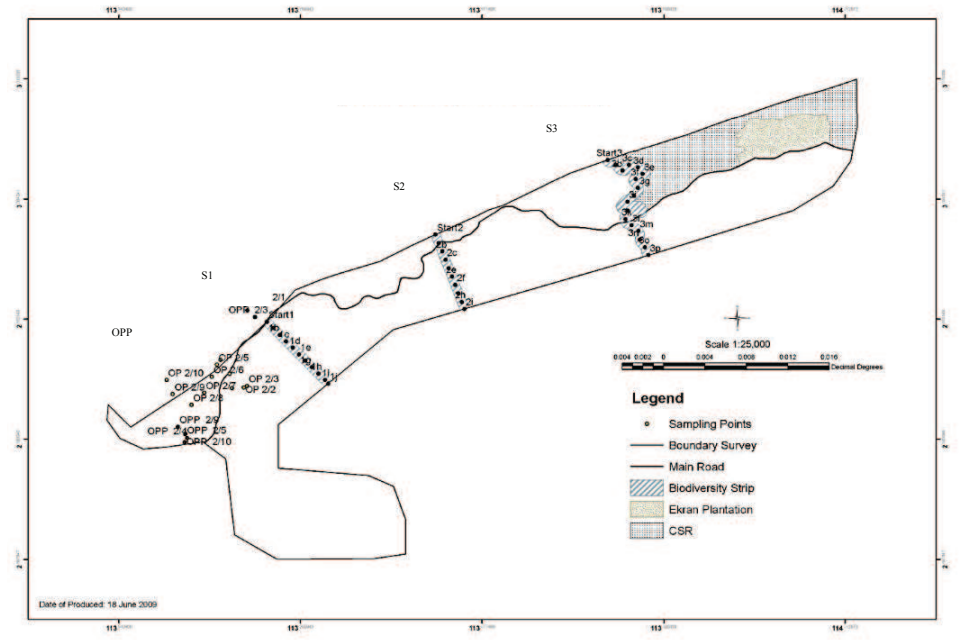

Note: (a) Oil palm cultivable area (OPCA), (b) strip 1 (S1), (c) strip 2 (S2), and (d) strip 3 (S3).

Figure 1. Global positioning system (GPS) sampling points sampling studied in Belaga, Sarawak, Malaysia.

\section{Phylogenetic Analysis}

Nucleotide sequences analysis in this study were aligned, and Neighbour-joining (NJ) trees were formed using MEGA version 5.0 (Molecular Evolutionary Genetics Analysis [http://www. megasoftware.net]). Kimura two-parameter substitution model with complete deletion of gapped sequence positions was used to construct Neighbourjoining phylogenetic trees based on the position of the $16 \mathrm{~S}$ rDNA. Resampling of the data was evaluated by 1000 bootstrap analysis to produce tree topologies and performed nodes with bootstrap values.

\section{Statistics for Biodiversity Index}

The Shannon-Weaver biodiversity index $\left(H^{\prime}\right)$, is calculated as follows:

$$
H^{\prime}=-\sum_{i=1}^{s} p_{i} \operatorname{In} p_{i}
$$

The letter $i$ in the formula represent each species' individual number or the abundance of each species, the letter $S$, is the species number, and $p i$ is the relative abundance of each species, calculated as the individuals of a given species to the total number of individuals in the ecosystem. The sigma symbol, $\Sigma$ is to sum up the formula equation. This is the simplest measures of species diversity. This diversity index is a common index, where, a high value of $H$ would signify a diverse and equally distributed community and lower values signify a lesser diverse community (Hill, 1973).

\section{Berger-Parker Dominance Index}

Berger-Parker dominance index states the relative importance of the most abundant species (the dominant species). It is the simplest measurement of the numerical importance of the most abundant species. The formula $\mathrm{d}=\mathrm{N}_{\max } / \mathrm{N}$ is where, Nmax is the total number of individuals in the most abundant species, and $N$ is the total number of individuals in the community (Hill, 1973).

Statistical analysis. The one-way analysis of variance (ANOVA), with post hoc Tukey test, were used to assess the significant differences in the total bands of the DGGE profiles. Differences were considered significant at $p<0.05$. All one-way ANOVA analysis was performed with Sigmaplot 12.0. Data was reported as, mean $\pm \mathrm{SE}$.

\section{RESULTS AND DISCUSSION}

The average total bands from DGGE in Figure 2, showed the area to be cultivated with oil palm has a total mean average bacterial group of $12.42 \pm 1.37$, whereas for biodiversity S1 and S3 was at the average of $11.2 \pm 2.00$ compared to biodiversity $\mathrm{S} 2$ which was the lowest at $8.12 \pm 0.98$. Statistically, biodiversity of the bacterial communities from biodiversity S2 was significantly less diversified as compared to the other sites with alpha, $\alpha<0.05$.

Based on Table 2, Shannon-Weaver prokaryotic biodiversity index showed highest values at OPCA at 7.423, followed by S1 at 7.001, S2 at 6.789 and the least diverse, $\mathrm{S} 3$ at 6.276. The results for Berger-Parker concurred, where the most diversified population was from OPCA, followed by S1, S3 and S2. Figure 3 shows that in logged over forest, unclassified bacteria group was the dominant phylum amongst the prokaryotic population in all of the sites. Acidobacteria group was the second most prevalent, followed by the Actinobacteria, $\alpha$-Proteobacteria, Firmicutes, and Chloroflexi group which were found in all sites. 
TABLE 2. MICROBIAL BIODIVERSITY INDICES FOR TOTAL MICROBES ON MINERAL SOIL SAMPLED FROM SG ASAP, BELAGA, SARAWAK, MALAYSIA

\begin{tabular}{|c|c|c|c|c|}
\hline Sites* & $\begin{array}{l}\text { Oil palm cultivable area } \\
\text { (OPCA) } \\
\text { (logged over forest) }\end{array}$ & Biodiversity strip 1 & Biodiversity strip 2 & Biodiversity strip 3 \\
\hline Shannon-Weaver biodiversity index & $7.423 \pm 0.043^{\mathrm{a}}$ & $7.001 \pm 0.056^{\mathrm{b}}$ & $6.789 \pm 0.014^{\mathrm{c}}$ & $6.276 \pm 0.01^{\mathrm{d}}$ \\
\hline Berger-Parker dominance index & $0.5742 \pm 0.014^{\mathrm{a}}$ & $0.5822 \pm 0.019^{\mathrm{b}}$ & $0.6628 \pm 0.053^{\mathrm{c}}$ & $0.5885 \pm 0.075^{\mathrm{d}}$ \\
\hline
\end{tabular}

Note: *Indices were compared using Tukey's method. Indices with the different letters are significantly different at $\mathrm{p}<0.05$.

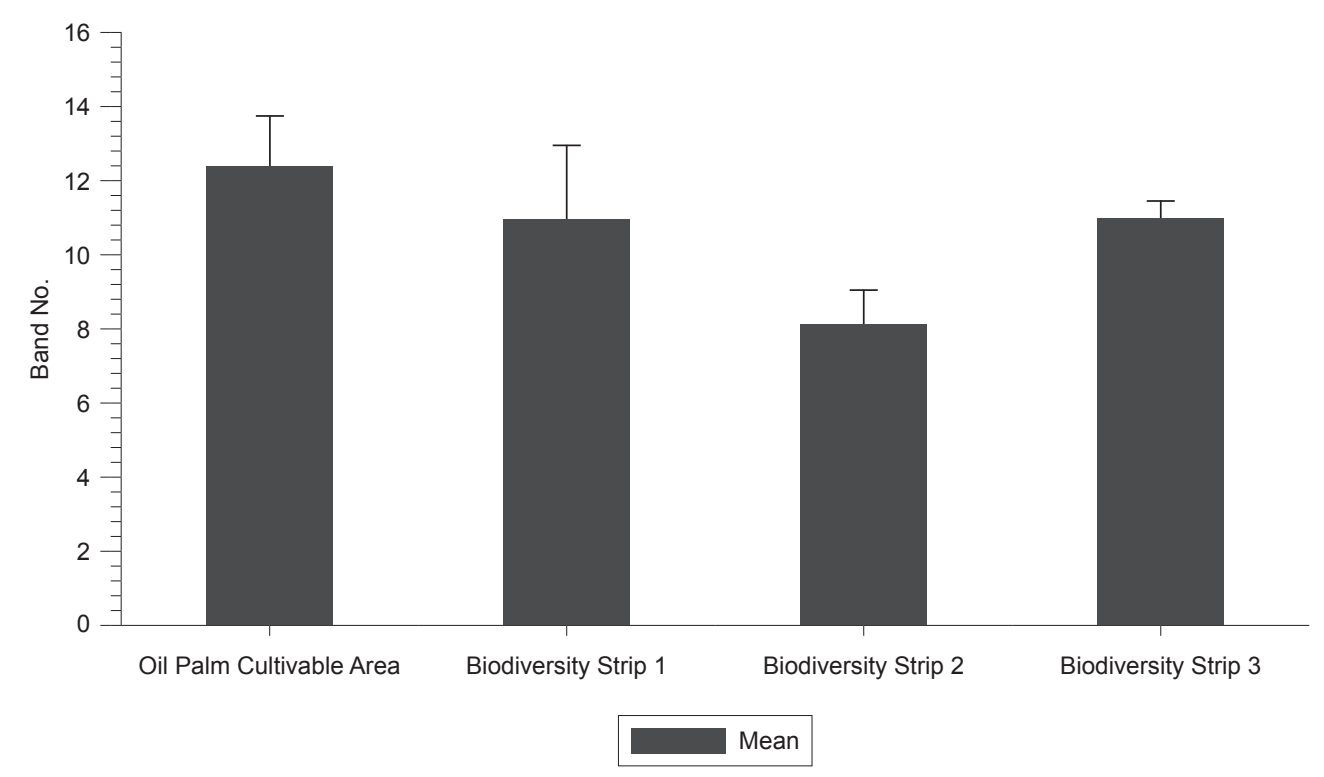

Figure 2. Average total bands from denaturing gradient gel electrophoresis (DGGE) of Belaga, logged over forest. One-way analysis of variance (ANOVA) with post hoc Tukey test was used to analyse the difference between sites. Bars in the same group with the same letter are not significantly different from one another at $p<0.05$.

The Proteobacteria groups, $\beta, \gamma$ and $\delta$ were only found in OPCA (Figure 3), and the Verrucomicrobia group was only found in riparian area, S3 (Figure $3 d$ ). However, S3 was the only site which did not harbour the Acidobacteria and Firmicutes groups. Unclassified bacteria group dominated all the sites with S3 (77\%), S1 (73\%), S2 (73\%) and OPCA $(46 \%)$. The prevalent Acidobacteria group mostly appeared in OPCA $(38 \%)$, followed by S2 (19\%) and S1 (9\%). Actinobacteria were found in all sites and predominated in S3 (13\%), OPCA (5\%), S2 (4\%) and S1 $(1 \%)$. The phylum $\alpha$-Proteobacteria was also found within all sites with highest occurrence in S3 $(8 \%)$, S1 $(4 \%)$, OPCA $(1 \%)$ and S2 $(1 \%)$. Firmicutes groups were prevalent in site S1 $(10 \%)$, OPCA $(4 \%)$ and S2 (1\%).

Figure 4 shows dominant types of common bacterial species for OPCA, namely, uncultured Acidobacteria bacterium (614 clones), uncultured Firmicutes bacterium (113 clones), uncultured Actinobacterium clones (56 clones), and Bradyrhizobium sp. (19 clones). Biodiversity strips commonly occurring bacterial species consist of uncultured Acidobacteria bacterium (600 clones), Actinopolyspora sp. (64 clones), uncultured Actinobacterium clone (58 clones), Bacillus sp. (46 clones) and uncultured Rhodoplanes sp. (39 clones) (Figure 5). Amongst the biodiversity strips the most diverse was S1, which comprised many species from the major phylum Acidobacteria, Firmicutes, $\alpha$-Proteobacteria and the minor phylum, Chloroflexi. The phylum Actinobacteria consisting of uncultured Actinobacterium clones (52 clones) and $\alpha$-Proteobacteria bacterial species, uncultured Rhodoplanes sp. (39 clones) were only abundant in riparian area of biodiversity S3.

The results showed that the area to be cultivated with oil palm was more diversed than strip areas, based on higher index values (Table 2) and the diverse population of phyla in that particular area (Figure 3). Based on previous studies, Acidobacteria and Proteobacteria are the predominant phyla group in forest soils (Nie et al., 2012; Lin et al., 2010) and Malaysian forest soils (Tripathi et al., 2014). Some studies had shown that acidity is one of the most important factors determining the growth of Acidobacteria in forest ecosystems (Jackson et al., 2009; Lin et al., 2010). Sampling sites OPCA, S1 and S2 showed that low soil $\mathrm{pH}(\mathrm{pH} 4.5-4.7)$ (Table 1), favours the growth of acidophilic Acidobacteria. Acidobacteria group was not found in S3, riparian forest. 
(a)

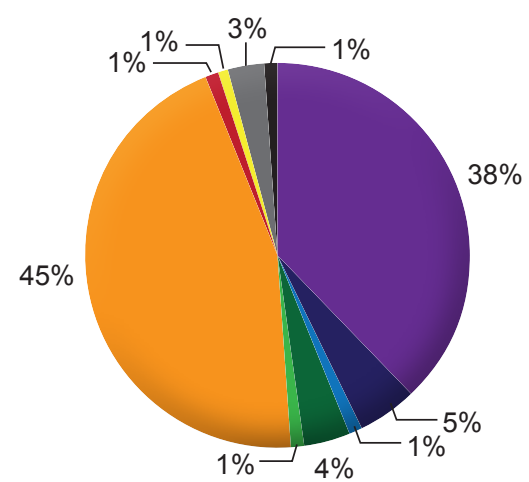

- Acidobacteria

Bacteroidetes

$\square$ Chloroflexi

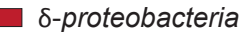

- $\alpha$-proteobacteria

(c)

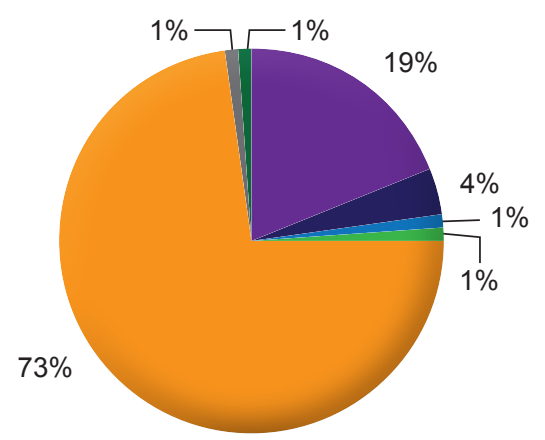

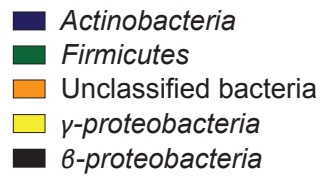

- b-proteobacteria (b)

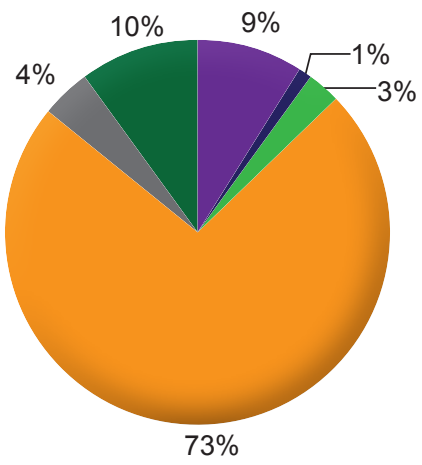

Acidobacteria

Chloroflexi

$\alpha$-proteobacteria
- Actinobacteria

$\square$ Unclassified bacteria

- Firmicutes

(d)

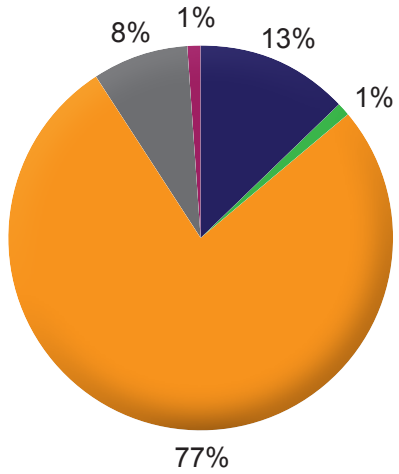

Verrucomicrobia

Actinobacteria

Chloroflexi

Unclassified bacteria

$\square$ Bacteroidetes

- Actinobacteria

Unclassified bacteria

$\square$ Chloroflexi

$\square$-proteobacteria

Note: (a) Oil palm cultivable area (OPCA), (b) strip 1, (c) strip 2, and (d) strip 3.

Figure 3. Prevalence of prokaryote phylum from Belaga sampling for biodiversity strips and oil palm sampled from Sg Asap, Belaga, Sarawak, Malaysia.

Acidobacteria was a dominant phylogenetic group found dominating in grasslands and in forests soil (Nacke et al., 2011). The abundance of Acidobacteria in forest soil may reflect the phylum's role in decomposition, which is an important ecological function suggested for Acidobacteria (Eichorst et al., 2011). The adaptability of Acidobacteria in heterotrophic metabolism allows them to live in numerous niches in the soil environment. Acidobacteria have been reported to dominate soils rich in soil organic matter and are involved in microbial degradation of lignocellulosic plant biomass (Eichorst et al., 2011; Pankratov et al., 2011). In the OPCA, Acidobacteria species commonly found were of uncultured Acidobacteria bacterium (Figure 4). These Acidobacteria species are heterotrophic and have the ability to grow on a variety of sugars or polysaccharides, with some species using amino acids as carbon sources. The enzymes of these Acidobacteria species have the capability to degrade plant cell wall polysaccharides, with complete enzymatic pathways (polysaccharide lyases and pectin esterases) involved in the degradation of pectins and hemicelluloses (Ward et al., 2009). These polymer-degrading enzyme characteristics revealed Acidobacteria as decomposers in the soil with the ability to contribute in the cycling of plant, fungal, and insect-derived organic matter to survive in environments where nutrients are low and thus, contributing to soil fertility (Fierer et al., 2007; Ward et al., 2009). 


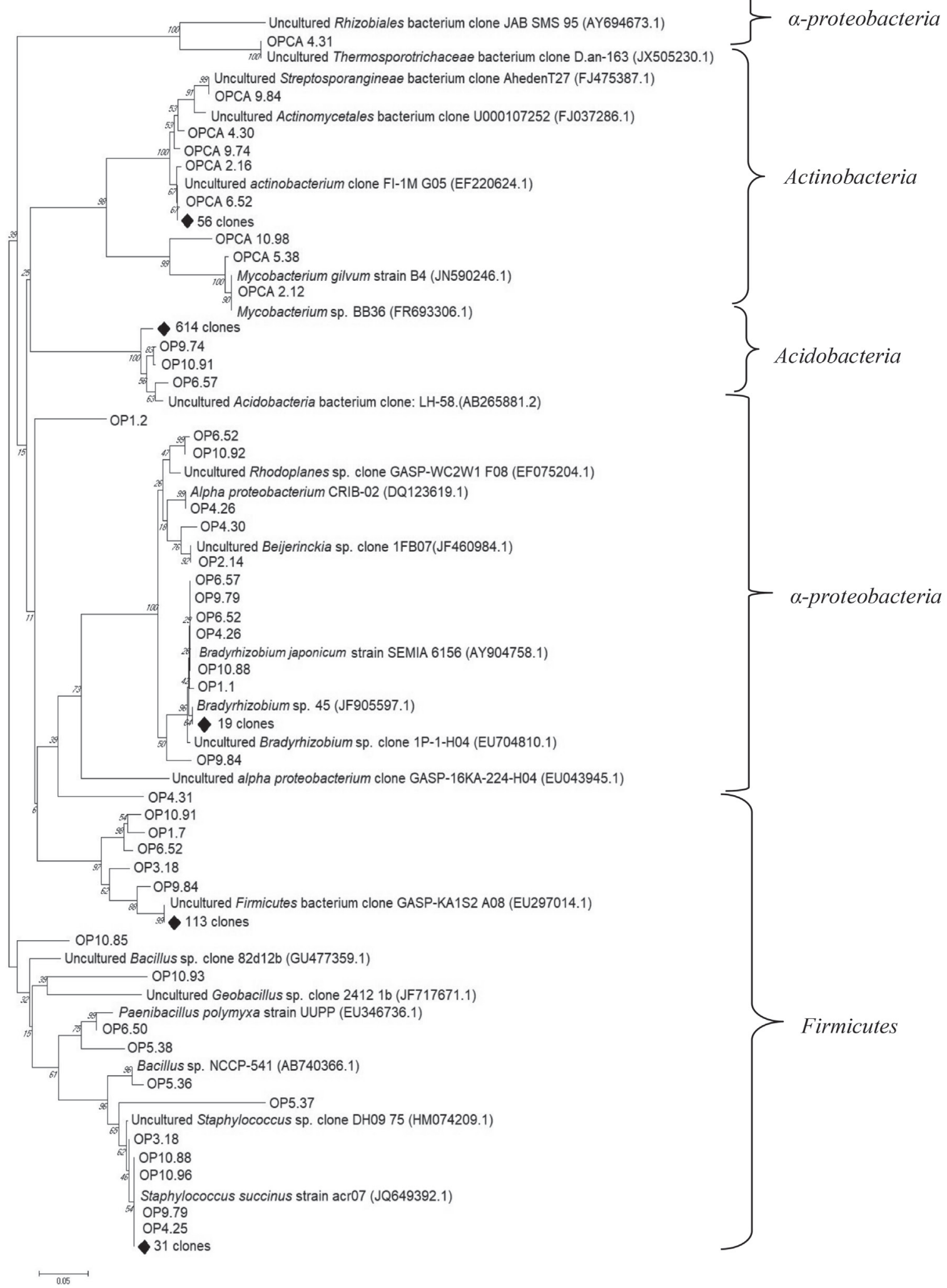

Figure 4. Phylogenetic tree based on similar nucleotide sequences detected by basic logic alignment search tool (BLAST), obtained from the dominant bacterial phyla isolated from Belaga of oil palm cultivable area (OPCA). The tree was constructed using the Kimura two-parameter algorithm and the Neighbour-joining method. Bootstrap values (expressed as percentages of 1000 replications) are reported at each node. The scale bar indicates 0.05 substitutions per nucleotide positions. 


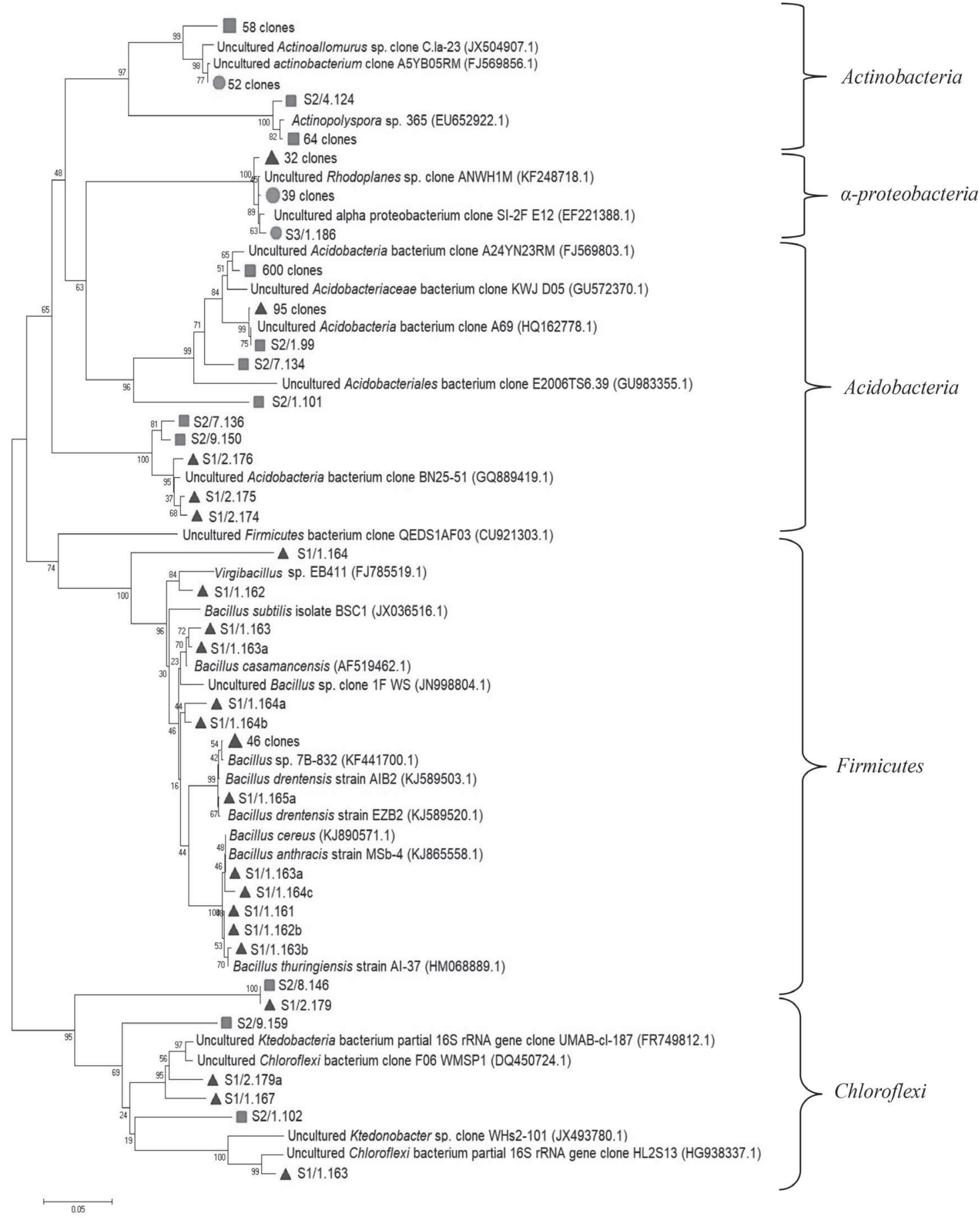

Figure 5. Phylogenetic tree based on similar nucleotide sequences detected by basic logic alignment search tool (BLAST), obtained from the dominant bacterial phyla isolated from Belaga of biodiversity strip areas. The tree was constructed using the Kimura two-parameter algorithm and the Neighbourjoining method. Bootstrap values (expressed as percentages of 1000 replications) are reported at each node. The scale bar indicates 0.05 substitutions per nucleotide positions. Legend shows biodiversity strips, S1 $\mathbf{\Lambda}, \mathrm{S} 2 \square$ and S3

The second prevalent phylum was Actinobacteria. This phylum that was predominant in OPP and S3 consists of species of uncultured Actinobacterium clone, Actinopolyspora sp. and Mycobacterium sp. The genus Mycobacterium was only present in OPCA (Figure 4). Actinobacteria is one of the predominant members of soil microbial communities and they have beneficial roles in soil nutrients cycling and agricultural productivity (García-Orenes et al., 2013). Species of the phylum, uncultured Actinobacterium clone generates extracellular enzymes for degradation of macromolecules such as cellulose, lignin, chitin, and starch. They often occur where degraded organic materials are abundant (Schafer $e t$ al., 2010).

Another important phylum was from the Proteobacteria group, the $\alpha$-Proteobacteria. This group is mostly abundant in soil ecosystems rich in organic materials with high carbon and moisture content (Shange et al., 2012) which explains its abundance in 
cultivable area of OPCA, riparian area, S3 and also in hilly jungle, S1 (Table 1). Major bacterial species from these phyla were uncultured Rhodoplanes sp. and Bradyrhizobium sp. (Figures 4 and 5). Bradyrhizobium isolates are able to produce IAA, solubilise phosphate and fix nitrogen which could be used for plant growth promotion. Similarly, higher shoot dry weight in plants inoculated with these strains may be attributed to more $\mathrm{N}$ supply to crop through $\mathrm{N}$ fixation by the bacteria (Meghvansi et al., 2010). Another bacterial species, Rhodoplanes are phototrophic bacteria found to be dominant in the soil rhizosphere and is regarded as being potential N fixers (Schostag et al., 2015). Members from this phylum enriches soil fertility by carbon, nitrogen and sulphur cycling, which are crucial functions in forest soils (Pastorelli et al., 2011).

The phylum Firmicutes was also another prevalent group in the OPCA. Species of Staphylococcus succinus and uncultured Firmicutes bacterium clones were the most predominant in this area. The phylum Firmicutes can utilise both inorganic and organic sources of nitrogen. Many species utilise ammonium salt as their sole nitrogen source, where mostly amino acids are widely utilised, and strains of some species can occasionally use urea (Hayat et al., 2010). In addition, phosphate solubilising bacteria such as species of Bacillus and Paenibacillus found in OPCA (Figure 4), improves the phosphorus level of plants with their ability to solubilise insoluble inorganic phosphate (mineral phosphate) compounds (Hayat et al., 2010). Staphylococcus succinus in the soil rhizosphere exhibits multifunctional plant growth promoter attributes (Verma et al., 2016).

Major phyla found in this study are consistent with other studies. For example, in German forests, where Actinobacteria was found abundant (Nacke et al., 2011). In the European Arctic soils, Acidobacteria and Proteobacteria survived based on low soil $\mathrm{pH}$ (Chu et al., 2010). In Malaysian soil, Acidobacteria, and Proteobacteria were recorded to be the dominant phyla (Miyashita et al., 2013).

\section{CONCLUSION}

Before the development of logged over forest for oil palm plantation, S2 was a hilly paddy area subjected to regular burning. This presumably has led to the significantly loss of diversified bacterial population than other sites. This study has also found that oil palm cultivable soils have a more diverse bacterial community than elevated jungle area or biodiversity strips area. Bacterial phylum in logged over forest of mineral soil was mostly dominated with unclassified bacteria followed by Acidobacteria, Actinobacteria and $\alpha$-Proteobacteria in the OPCA, biodiversity S1 and S2. In riparian area of S3, only phyla Actinobacteria and $\alpha$-Proteobacteria was the abundant group whereas Acidobacteria group was not found in biodiversity S3, where the $\mathrm{pH}$ was less acidic. Secondary logged over forest was mostly dominated by Acidobacteria, which comprised of many strains belonging to the family Acidobacteriaceae. The phylum Actinobacteria was the next predominating group of microbes comprising of the bacterial species belonging to the family of Actinomycetaceae, and Mycobacteriaceae. Strains from the phylum, $\alpha$-Proteobacteria was also prevalent with the family group belonging to Hyphomicrobiaceae and Bradyrhizobiaceae. Common species found for all sites were uncultured Acidobacteria bacterium (Acidobacteriaceae), uncultured Actinobacterium clones (Actinomycetaceae) and uncultured Rhodoplanes sp. (Hyphomicrobiaceae).

\section{ACKNOWLEDGEMENT}

The authors would like to thank the DirectorGeneral of MPOB for permission to publish this article. The authors also would like to extend their appreciation to Dr Siti Ramlah Ahmad Ali for reviewing this article.

\section{REFERENCES}

Chu, H; Fierer, N; Lauber, C L; Caporaso, J G; Knight, $\mathrm{R}$ and Grogan, P (2010). Soil bacterial diversity in the Arctic is not fundamentally different from that found in other biomes. Environ. Microbiol., 12: 29983006.

Dumbrell, A J; Nelson, M; Helgason, T; Dytham, C and Fitter, A H (2010). Relative roles of niche and neutral process in structuring a soil microbial community. ISME J., 4: 337-345.

Eichorst, S A; Kuske, C R and Schmidt, T M (2011). Influence of plant polymers on the distribution and cultivation of bacteria in the phylum Acidobacteria. Applied Environmental Microbiology Vol. 77 No. 2: 586596.

Erwin, T L (1991). An evolutionary basis for conservation strategies. Science, 253: 750-752.

Fierer, N; Bradford, M A and Jackson, R B (2007). Towards an ecological classification of soil bacteria. Ecology, 88: 1354-1364.

García-Orenes, F; Morugán-Coronado, A; Zornoza, $\mathrm{R}$ and Scow, $\mathrm{K}$ (2013). Changes in soil microbial community structure influenced by agricultural management practices in a Mediterranean agroecosystem. PLoS ONE, 8(11): E80522. 
Hayat, R; Ali, S; Amara, U; Khalid, R and Ahmed, I (2010). Soil beneficial bacteria and their role in plant growth promotion: A review. Annals of Microbiology, 60(4): 579-598.

Hill, M O (1973). Diversity and evenness: A unifying notation and its consequences. Ecol., 54: 427-431.

Jackson, C R; Liew, K C and Yule, C M (2009). Structural and functional changes with depth in microbial communities in a tropical Malaysian peat swamp forest. Microb. Ecol., 57: 402-412.

Koh, L P; Miettinen, J; Liew, S C and Ghazoul, J (2011). Remotely sensed evidence of tropical peatland conversion to oil palm. Proc. Natl. Acad. Sci. USA, 108: 5127-5132.

Kushairi, A; Soh Kheang Loh; Azman, I; Elina Hishamuddin; Meilina Ong-Abdullah; Zanal Bidin Mohd Noor Izuddin; Razmah, G; Shamala Sundram and Ghulam Kadir Ahmad Parveez (2018). Oil palm economic performance in Malaysia and R\&D progress in 2017. J. Oil Palm Res. Vol. 30(2): 163195.

Lin, Y T; Huang, Y J; Tang, S L; Whitman, W B; Coleman, D C and Chiu, C Y (2010). Bacterial community diversity in undisturbed perhumid montane forest soils in Taiwan. Microb. Ecol., 59: 369378.

Meghvansi, M K; Prasad, K and Mahna, S K (2010). Symbiotic potential, competitiveness and compatibility of indigenous Bradyrhizobium japonicum isolates to three soybean genotypes of two distinct agro-climatic regions of Rajasthan, India. Saudi J. Biol. Sci., 17: 303-310.

Miyashita, N T; Iwanaga, $\mathrm{H}$; Charles, S; Diway, B and Sabang, J (2013). Soil bacterial community structure in five tropical forests in Malaysia and one temperate forest in Japan revealed by pyrosequencing analyses of $16 \mathrm{~S}$ rRNA gene sequence variation. Genes Genet. Syst., 88: 93103.

Muyzer, G; De Waal, E C and Uitterlinden, A G (1993). Profiling of complex microbial populations by denaturing gradient gel electrophoresis analysis of polymerase chain reaction-amplified genes coding for 165 rRNA. Appl. Environ. Microbiol., 59(3): 695-700.

Nacke, H; Thürmer, A; Wollherr, A and Will, C (2011). Pyrosequencing-based assessment of bacterial community structure along different management types in German forest and grassland soils. PLoS ONE, 6: e17000.
Nie, M; Meng H; Li K; Wan, J R; Quan, Z X; Fang, C M; Chen, J K and Li, B (2012). Comparison of bacterial and fungal communities between natural and planted pine forests in subtropical China. Curr. Microbiol., 64: 34-42.

Pankratov, TA; Ivanova, AO;Dedysh, SN and Liesack, W (2011). Bacterial populations and environmental factors controlling cellulose degradation in an acidic Sphagnum peat. Environ. Microbiol., 13: 1800-1814.

Pastorelli, R; Landi, S; Trabelsi, D; Piccolo, R and Mengoni, A (2011). Effects of soil management on structure and activity of denitrifying bacterial communities. Appl. Soil Ecol., 49: 46-58.

Rodrigues, J L M; Pellizari, V H; Mueller, R; Baek, K; Jesus, E D C; Paula, F S; Mirza, B; Hamaoui, G S; Tsai, S M; Feigl, B; Tiedje, J M; Bohannan, B J M and Nüsslein, K (2012). Conversion of the Amazon rainforest to agriculture results in biotic homogenisation of soil bacterial communities. Proc. Natl. Acad. Sci. USA, 110: 988-993.

Saman, S; Slattery, P and Saman, S (2010). Microbial biodiversity investigation techniques. Current Research, Technology and Education Topics in Applied Microbiology and Microbial Biotechnology (MendezVilas, A ed.). p. 1546-1550.

Schäfer, J; Jäckel, U and Kämpfer, P (2010). Development of a new PCR primer system for selective amplifiation of Actinobacteria. FEMS Microbiol Let., 311: 103-112.

Shange, R S; Ankumah, R O; Ibekwe, A M; Zabawa, $R$ and Dowd, S E (2012). Distinct soil bacterial communities revealed under a diversely managed agroecosystem. PLoS ONE, 7: e40338. DOI:10.1371/ journal.pone.0040338.

Schostag, M; Stibal, M; Jacobsen, C S; Baelum, J; $\mathrm{Ta}_{3} \mathrm{~S} \mathrm{~N}$ and Elberling, B (2015). Distinct summer and winter bacterial communities in the active layer of Svalbard permafrost revealed by DNA- and RNAbased analyses. Front. Microbiol., 6: 399. DOI: 10.3389/ fmicb.2015.00399.

Tripathi, M B; Lee-Cruz, L; Kim, M; Singh, D; Go, R and Noraini, A (2014). Spatial scaling effects on soil bacterial communities in Malaysian tropical forests. Microb. Ecol., 68: 247-258.

Van Der Heijden, M G A; Bardgett, R D and Van Straalen, N M (2008). The unseen majority: Soil microbes as drivers of plant diversity and productivity in terrestrial ecosystems. Ecol. Lett., 11: 296-310. 
Verma, P; Yadav, A N; Khannam, K S; Kumar, S; Saxena, A K and Suman, A (2016). Molecular diversity and multifarious plant growth promoting attributes of Bacilli associated with wheat (Triticum aestivum L.) rhizosphere from six diverse agroecological zones of India. J. Basic Microbiol., 56(1): 44-58.

Wahid, M B; Abdullah, S N A and Henson, I E (2005). Oil palm - Achievements and potential. Plant Prod. Sci., 8: 288-297.

Ward, N L; Challacombe, J F; Janssen, P H; Henrissat, B; Coutinho, P M; Wu, M; Xie, G; Haft, D H; Sait, M; Badger, J; Barabote, R D; Bradley, B; Brettin, T S; Brinkac, L M; Bruce, D; Creasy, T; Daugherty, S
C; Davidsen, T M; Deboy, R T; Detter, J C; Dodson, R J; Durkin, A S; Ganapathy, A; Gwinn-Giglio, M; Han, C S; Khouri, H; Kiss, H; Kothari, S P; Madupu, R; Nelson, K E; Nelson, W C; Paulsen, I; Penn, K; Ren, Q H; Rosovitz, M J; Selengut, J D; Shrivastava, S; Sullivan, S A; Tapia, R; Thompson, L S; Watkins, K L; Yang, Q; Yu, C H; Zafar, N; Zhou, L W and Uske, C R (2009). Three genomes from the phylum Acidobacteria provide insight into the lifestyles of these microorganisms in soils. Appl. Environ. Microbiol., 75: 2046-2056.

Zarkasi, K Z and Nazari, T F (2018). Molecular characterisation of microbial diversity associated with oysters within a commercial oyster farm. Turkish J. Fisheries and Aquatic Sciences, 18(1): 191-197.

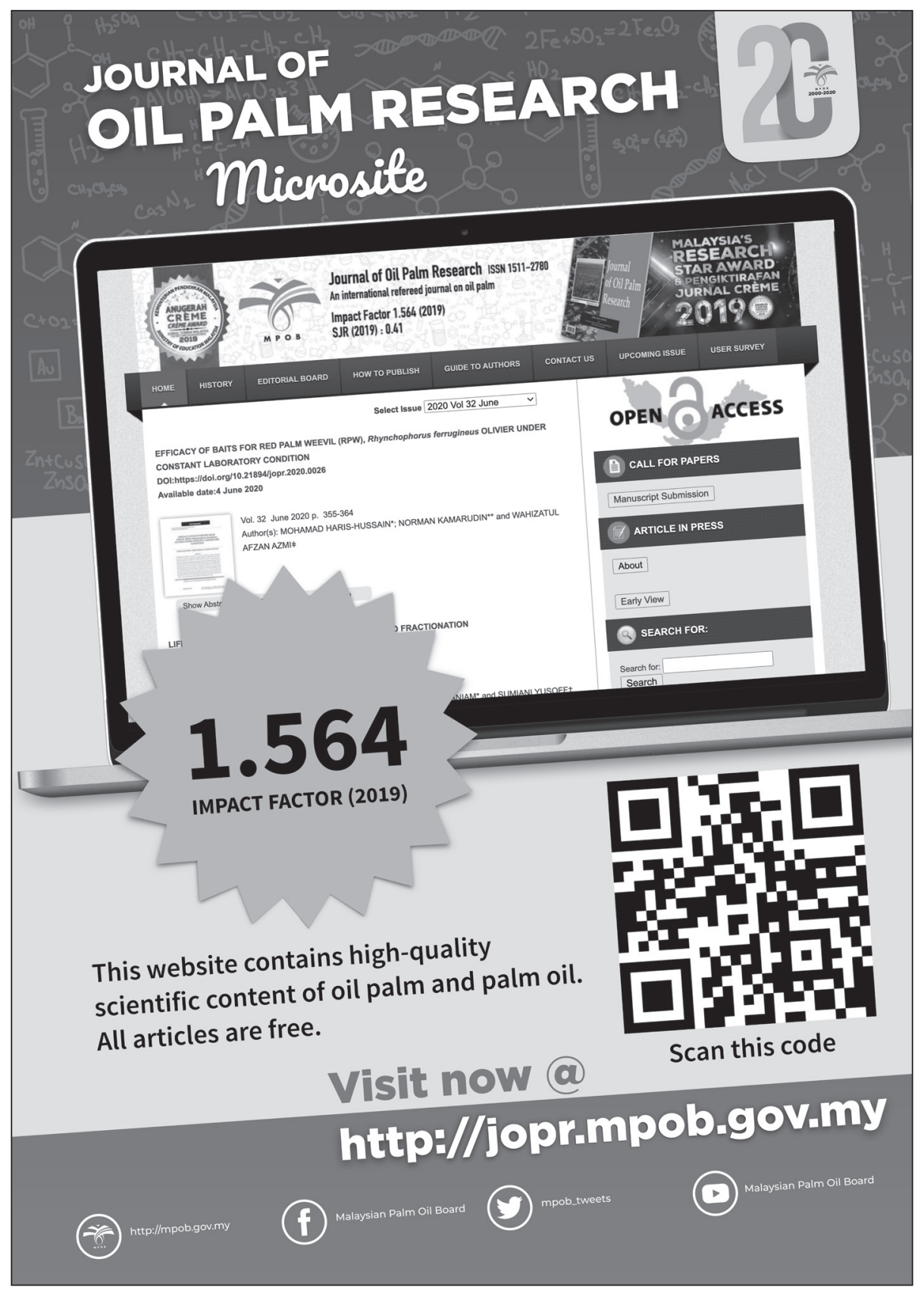

